\title{
Związek partnerski czy małżeństwo? Ocena prawna poselskich projektów: ustawy o związku partnerskim oraz ustawy - Przepisy wprowadzające ustawę o związku partnerskim ${ }^{1}$
}

\footnotetext{
Partnership or marriage? Evaluation of Deputies' Bills - on Partnership and Introductory Provisions of the Act on Partnership (WAP-1448/18): In the author's opinion, the proposed provisions - contrary to their nomenclature - introduce an institution of samesex marriages. Therefore they may be considered incompatible with Article 18 of the Constitution of the Republic of Poland. The proposed regulations regarding the dissolution of the partnership provide less protection to the children of partners than the children of one of them adopted by the other, what is inconsistent with the constitutional principle of equality. Besides the bills contain many legal shortcomings.
}

Keywords: bill, partnership

Słowa kluczowe: projekt ustawy, związek partnerski

\section{Przedmiot opinii}

Opinia dotyczy poselskich projektów ustaw:

- o związku partnerskim, dalej: projekt o z.p.,

- Przepisy wprowadzające ustawę o związku partnerskim, dalej: projekt przep. wprow.u.z.p.,

W niniejszej opinii uwzględniono postanowienia następujących aktów prawnych:

- Konstytucja Rzeczypospolitej Polskiej z 2 kwietnia 1997 r., Dz.U. nr 78, poz. 483, ze zm.; dalej: Konstytucja lub Konstytucja RP,

Opinia prawna dotyczaca poselskiego projektu ustawy o zwiazku partnerskim oraz poselskiego projektu ustawy - Przepisy wprowadzajace ustawe o zwiąku partnerskim sporządzona 20 czerwca 2018 r. na zlecenie Szefa Kancelarii Sejmu; BAS-WAP $1448 / 18$. 
- ustawa z 25 lutego 1964 r. - Kodeks rodzinny i opiekuńczy, t.j. Dz.U. 2017, poz. 682 , ze zm.; dalej: k.r.o.,

- ustawa z 28 listopada 2014 r. - Prawo o aktach stanu cywilnego, t.j. Dz.U. 2016, poz. 2064, ze zm.; dalej: u.p.a.s.c.,

- ustawa z 23 kwietnia 1964 r. - Kodeks cywilny, t.j. Dz.U. 2018, poz. 1025; dalej: k.c.,

- ustawa z 4 lutego 2011 r. - Prawo prywatne międzynarodowe, t.j. Dz.U. 2015, poz. 1792,

- ustawa z 24 lipca 1998 r. o zmianie ustaw - Kodeks rodzinny i opiekuńczy, Kodeks postępowania cywilnego, prawo o aktach stanu cywilnego, ustawy o stosunku Państwa do Kościoła katolickiego w Rzeczypospolitej Polskiej oraz niektórych innych ustaw, Dz.U. nr 117, poz. 757,

- estoński kodeks prawa rodzinnego (Perekonnaseadus/Family Law Act) z 18 listopada $2009 \mathrm{r}$.,

- niemiecki kodeks cywilny z 1896 r. (Bürgerliches Gesetzbuch),

- portugalski kodeks cywilny (Código Civil) z 25 listopada 1966 r.,

- rumuński kodeks cywilny (Codul civil) z 17 lipca 2009 r.,

- chilijska ustawa nr 19947 o małżeństwie cywilnym (Ley núm. 19.947, Nueva Ley de matrimonio civil).

\section{Zakres proponowanych zmian}

W uzasadnieniu do projektu ustawy o związku partnerskim zadeklarowano, że: [c]elem głównym (...) ustawy jest realizacja art. 18 Konstytucji - zapewnienia opieki i ochrony Rzeczypospolitej Polskiej rodzinom, które do tej pory takiej ochrony były pozbawione ${ }^{2}$. W tym celu w projekcie określa się prawne ramy funkcjonowania związków nieformalnych, wprowadzając możliwość wstąpienia w związek partnerski zarówno przez pary różnej, jak i tej samej płci.

Natomiast celem projektu ustawy - Przepisy wprowadzające ustawę o związku partnerskim jest nowelizacja 148 ustaw, których zmiana jest - zdaniem projektodawcy - konieczna ze względu na wprowadzenie nieznanej prawu polskiemu instytucji związku partnerskiego ${ }^{3}$.

2 Pkt 1 uzasadnienia do poselskiego projektu ustawy o związku partnerskim.

3 Zob. pkt 1 uzasadnienia do poselskiego projektu ustawy - Przepisy wprowadzające ustawę o związku partnerskim. 


\section{Ocena proponowanych rozwiązań}

\section{Wstęp}

Fundamentalnym problemem, który powstaje na gruncie obu przedstawionych projektów, jest konstytucyjna dopuszczalność wprowadzenia do systemu prawa polskiego instytucji związku partnerskiego, dlatego w pierwszej kolejności projekty winny zostać ocenione w świetle postanowień ustawy zasadniczej. Dokonując takiej oceny, przede wszystkim należy wziąć pod uwagę art. 18 Konstytucji, który stanowi, że: [m]ałżeństwo jako związek kobiety i mężczyzny, rodzina, macierzyństwo i rodzicielstwo znajduja się pod ochrona i opieka Rzeczypospolitej Polskiej.

Przytoczony wyżej przepis Konstytucji, choć nie definiuje w pełni pojęcia „małżeństwa”, to jednak expressis verbis wskazuje, że od strony podmiotowej tworzą je mężczyzna i kobieta. A contrario wynika z niego, że za małżeństwo nie może być uznany związek osób tej samej płci, a tym samym regulacja dopuszczająca zawieranie małżeństw jednopłciowych byłaby niezgodna $\mathrm{z}$ art. 18 Konstytucji ${ }^{4}$.

Chociaż projekty dotyczą wprowadzenia instytucji związku partnerskiego, to jednak kwestia stosowanej nomenklatury nie może być w tym przypadku rozstrzygająca, bowiem o tym, czy zarejestrowany związek dwojga osób jest małżeństwem, nie może przesądzać nazewnictwo, lecz charakter prawny tworzonej instytucji. W związku z tym, aby stwierdzić, czy wprowadzenie projektowanych rozwiązań byłoby zgodne z Konstytucją, warto porównać je z obowiązującymi unormowaniami dotyczącymi małżeństwa i, diagnozując występujące między nimi podobieństwa oraz różnice, ocenić, czy pomimo zmiany nazewnictwa kreowana przez projekty instytucja może uchodzić za małżeństwo.

\section{Małżeństwo a związek partnerski}

\section{- Przesłanki zawarcia małżeństwa oraz związku partnerskiego}

Mając na uwadze postanowienia Kodeksu rodzinnego i opiekuńczego, należy wskazać następujące przesłanki zawarcia małżeństwa:

- odmienność płci nupturientów (art. $1 \$ 1$ k.r.o.),

- jednoczesna obecność przyszłych małżonków składających oświadczenia woli (art. $1 \S 1$ k.r.o.) $)^{5}$,

4 Por. L. Garlicki, Komentarz do art. 18 [w:] Konstytucja Rzeczypospolitej Polskiej. Komentarz, t. I, red. L. Garlicki, M. Zubik, Warszawa 2016, s. 491-491; W. Borysiak, Komentarz do art. 18 [w:] Konstytucja RP, t. I, Komentarz. Art. 1-86, red. M. Safjan, L. Bosek, Warszawa 2016, nb 112-119.

5 Wyjątek od tej zasady formułuje art. 6 k.r.o. określający warunki zawarcia małżeństwa przez pełnomocnika. 
- złożenie zgodnych oświadczeń woli przed podmiotem uprawnionym do ich odebrania, tj.

- kierownikiem urzędu stanu cywilnego (art. $1 \$ 1$ oraz art. $9 \$ 1$ k.r.o.),

- duchownym, jeżeli kierownik urzędu stanu cywilnego sporządzi następnie akt małżeństwa (art. $1 \$ 2$ i 3 , art. $9 \$ 2$ k.r.o.),

- polskim konsulem lub osobą wyznaczoną do wykonywania funkcji konsula, jeżeli nupturienci przebywają za granicą (art. $1 \S 4$ k.r.o.).

Zgodnie z art. 2 k.r.o., jeżeli mimo niezachowania wyżej wskazanych wymogów sporządzony został akt małżeństwa, każdy, kto ma w tym interes prawny, może wystąpić z powództwem o ustalenie nieistnienia małżeństwa. Poza tym powództwo o ustalenie istnienia lub nieistnienia małżeństwa może wytoczyć także prokurator (art. 22 k.r.o.).

Natomiast $\mathrm{w}$ świetle postanowień projektu o z.p przesłankami zawarcia związku partnerskiego są:

- jednoczesna obecność partnerów składających oświadczenie woli (art. 7 ust. 4),

- złożenie zgodnych oświadczeń woli przed podmiotem uprawnionych do ich odebrania, tj.

- kierownikiem urzędu stanu cywilnego (art. 7 ust. 4),

- polskim konsulem lub osobą wyznaczoną do wykonywania funkcji konsula, jeżeli nupturienci przebywają za granicą (art. 7 ust. 8).

Zgodnie $\mathrm{z}$ art. 9 ust. 2 projektu o z.p., jeżeli pomimo niezachowania tych wymogów został sporządzony akt związku partnerskiego, prokurator oraz każdy, kto ma w tym interes prawny, może wystąpić z powództwem o ustalenie nieistnienia takiego związku'

Porównanie przesłanek warunkujących zawarcie małżeństwa i związku partnerskiego pokazuje, że są one niemalże identyczne. Jednak, co należy podkreślić, występujące różnice są zupełnie nieistotne. Zrozumiałe jest to, że przesłanka odmienności płci partnerów nie może być uwzględniona w przypadku związku partnerskiego, mającego wszak nadawać ramy prawne pożyciu par jednopłciowych. Z kolei przewidziana przez art. 6 k.r.o. możliwość zawarcia małżeństwa przez pełnomocnika jest rozwiązaniem dopuszczalnym tylko w wyjątkowych sytuacjach i nie przekreśla zasady osobistego stawiennictwa nupturientów. Poza tym brak analogicznych unormowań w projekcie o z.p. powinien być postrzegany raczej nie jako odmienność, ale jako wada proponowanej regulacji. Również możliwość wstąpienia w związek małżeński przed duchownym jest rozwią-

${ }_{6}$ W art. 9 ust. 2 błędnie odwołano się do art. 6 ust. 4 i 8 projektu o z.p., bowiem art. 6 nie jest podzielony na ustępy. W związku z tym można przypuszczać, iż chodzi o art. 7 ust. 4 i 8 projektu o z.p. 
zaniem fakultatywnym wobec podstawowego sposobu zawierania małżeństwa przed kierownikiem urzędu stanu cywilnego, a co więcej przez dziesięciolecia był to sposób nieznanym prawu polskiemu7. W związku z powyższym trzeba stwierdzić, iż prawna konstrukcja przesłanek (nie)istnienia małżeństwa oraz związku partnerskiego jest - przynajmniej co do istoty - taka sama.

\section{- Warunki formalne zawarcia małżeństwa oraz związku partnerskiego}

Zgodnie z art. $3 \$ 1$ k.r.o. osoby zamierzające zawrzeć małżeństwo powinny złożyć lub przedstawić kierownikowi urzędu stanu cywilnego dokumenty niezbędne do zawarcia małżeństwa, określone w odrębnych przepisach. Mając na uwadze, że art. $3 \$ 1$ k.r.o. odsyła do art. 76 u.p.a.s.c., należy stwierdzić, że analogiczne rozwiązania zawiera art. 7 ust. 2 projektu o z.p., który przewiduje, że osoby zamierzające zawrzeć związek partnerski powinny złożyć kierownikowi urzędu stanu cywilnego dokumenty, o których mowa w art. 76 u.p.a.s.c. Jedynym elementem nieistotnie różnicującym oba przepisy jest to, iż ten pierwszy dopuszcza złożenie lub przedstawienie dokumentów, ten drugi zaś tylko złożenie.

Pomiędzy przepisami dotyczącymi zawarcia małżeństwa i związku partnerskiego występują także inne podobieństwa. Według art. 8 projektu o z.p. oświadczenia o wstąpieniu w związek partnerski powinny być złożone publicznie, w obecności dwóch pełnoletnich świadków, czyli tak samo jak oświadczenia składane przez nupturientów mających zamiar zawrzeć małżeństwo (zob. art. 7 $\$ 1$ k.r.o.).

Ponadto należy zauważyć, że art. $7 \$ 3$ k.r.o. stanowi: Każda $z$ osób zawierających małżństwo składa oświadczenie o wstąpieniu w związek małżeński, powtarzajac za kierownikiem urzędu stanu cywilnego treść oświadczenia lub odczytując je na głos: „Świadomy/Świadoma praw i obowiązków wynikających z zawarcia małżństwa uroczyście oświadczam, że wstępuję $w$ związek małżeński $z$ (imię $i$ nazwisko drugiej z osób wstępujących $w$ związek mał̇̇enski) i przyrzekam, że uczynię wszystko, aby nasze małżeństwo było zgodne, szczęśliwe i trwałe”. Osoba niemogąca mówić składa oświadczenie o wstapieniu $w$ związek małżeński, podpisując protokół przyjęcia oświadczeń o wstapieniu w związek małżeński. Niemalże identyczne rozwiązania zawierają również przepisy projektu o z.p. I tak art. 7 ust. 4 przewiduje, że: [d]wie osoby jednocześnie obecne składaja przed kierownikiem urzędu stanu cywilnego oświadczenia, że wstępuja ze sobą w związek partnerski, powtarzając za kierownikiem urzędu stanu cywilnego treść oświadczenia lub odczytując je na głos. Osoba niemogąca mówić składa oświadczenie o wstąpieniu w związek, podpisując protokót przyjęcia oświadczeń o wstąpieniu w związek

Możliwość zawarcia małżeństwa przed duchownym została wprowadzona ustawą o zmianie ustaw - Kodeks rodzinny i opiekuńczy, Kodeks postępowania cywilnego, prawo o aktach stanu cywilnego, ustawy o stosunku Państwa do Kościoła katolickiego w Rzeczypospolitej Polskiej oraz niektórych innych ustaw. 
partnerski. Z kolei zgodnie z art. 7 ust. 5 projektu o z.p. oświadczenie, o którym mowa w art. 7 ust. 4 tego projektu, brzmi w sposób następujący: Świadomy/ Świadoma praw i obowiązków wynikajacych z zawarcia związku partnerskiego uroczyście oświadczam, że wstępuję w zwiąek partnerski z (imię i nazwisko drugiej $z$ osób wstępujących $w$ związek) i przyrzekam, że uczynię wszystko, aby nasz związek był zgodny, szczęśliwy i trwaty.

Innym elementem wspólnym występującym przy zawarciu małżeństwa i związku partnerskiego jest ogłoszenie przez kierownika urzędu stanu cywilnego, iż związek partnerski/małżeństwo został(-o) zawarte (art. $7 \$ 4$ k.r.o. oraz art. 7 ust. 6 projektu o z.p.).

Reasumując, należy stwierdzić, że w zakresie warunków formalnych zawarcia małżeństwa oraz związku partnerskiego brak jest istotnych różnic.

\section{- Przesłanki unieważnienia małżeństwa oraz związku partnerskiego}

W świetle art. 13 ust. 1-2 projektu o z.p. związek partnerski może być unieważniony tylko w następujących przypadkach:

- jeżeli został zawarty przez osobę, która nie ukończyła lat osiemnastu albo która ukończyła lat szesnaście, lecz nie uzyskała zezwolenia na zawarcie związku,

- jeśli decyzja o zawarciu związku nie została podjęta w sposób świadomy i swobodny,

- jeśli związek partnerski został zawarty między przysposabiającym i przysposabianym,

- jeśli przynajmniej jeden z partnerów pozostaje w poprzednio zawartym małżeństwie albo związku partnerskim,

- jeśli został zawarty między krewnymi w linii prostej, rodzeństwem, powinowatymi w linii prostej albo jeśli został zawarty między powinowatymi bez zgody sądu,

- jeśli oświadczenie o zawarciu związku partnerskiego zostało złożone pod wpływem błędu co do tożsamości drugiej strony albo pod wpływem bezprawnej groźby drugiej strony lub osoby trzeciej, jeżeli z okoliczności wynika, że składający oświadczenie mógł się obawiać, iż jemu samu lub innej osobie grozi poważne niebezpieczeństwo osobiste.

Zgodnie z postanowieniami projektu o z.p. unieważnienia związku partnerskiego z przyczyn, o których mowa wyżej w pkt 1-3, może żądać każdy z partnerów (art. 13 ust. 3), zaś z przyczyn, o których mowa w pkt 4-5, każdy kto, ma w tym interes prawny (art. 13 ust. 4). Co istotne, związku partnerskiego nie można unieważnić z powodu braku przepisanego wieku, jeżeli partner przed wytoczeniem powództwa ten wiek osiągnął (art. 5 ust. 3 projektu o z.p.). Z kolei unieważnienia związku partnerskiego z przyczyny, o której mowa wyżej w pkt 6, może żądać partner, który złożył oświadczenie dotknięte wadą. Przy czym nie można żądać unieważnienia związku partnerskiego po upływie sześciu miesięcy 
od wykrycia błędu lub ustania obawy wywołanej groźbą - a w każdym przypadku po upływie trzech lat od zawarcia związku (art. 13 ust. 5 projektu o z.p.).

WIEK W zasadzie $\mathrm{z}$ analogicznych przyczyn można obecnie unieważnić małżeństwo. A mianowicie, zgodnie z art. $10 \$ 2$ k.r.o. unieważnienia małżeństwa zawartego przez mężczyznę, który nie ukończył lat osiemnastu, oraz przez kobietę, która nie ukończyła lat szesnastu, albo bez zezwolenia sądu zawarła małżeństwo po ukończeniu lat szesnastu, lecz przed ukończeniem lat osiemnastu, może żądać każdy z małżonków. Ponadto art. $10 \$ 3$ k.r.o. przewiduje, że nie można unieważnić małżeństwa $\mathrm{z}$ powodu braku przepisanego wieku, jeżeli małżonek przed wytoczeniem powództwa ten wiek osiągnął. Projektowane przepisy dotyczące związków partnerskich różnią się od obowiązujących regulacji Kodeksu rodzinnego i opiekuńczego odnoszących się do małżeństw tym, że dopuszczają, aby partner płci męskiej zawarł związek po ukończeniu szesnastego roku życia za zgodą sądu oraz tym, iż zezwalają, by partner będący mężczyzną żądał unieważnienia związku z powodu braku przepisanego wieku po tym, gdy partnerka płci żeńskiej zaszła w ciążę.

Na marginesie warto wskazać, że art. 4 ust. 2 projektu o z.p. określa również takie same przesłanki wyrażenia przez sąd opiekuńczy zgody na zawarcie związku partnerskiego przez osobę, która ukończyła lat szesnaście, jak art. $10 \$ 1$ k.r.o., który dotyczy sądowej zgody na wstąpienie w związek małżeński przez kobietę, która ukończyła lat szesnaście.

Przysposobienie Kontynuując analizę dotyczącą przyczyn unieważnienia małżeństwa oraz związku partnerskiego, należy zauważyć, że art. $15 \$ 1$ k.r.o. przewiduje, iż nie mogą zawrzeć ze sobą małżeństwa przysposabiający i przysposobiony. Taki sam zakaz w odniesieniu do związków partnerskich zawiera także art. 5 ust. 1 projektu o z.p. W przypadku małżeństwa unieważnienia z powodu stosunku przysposobienia może żądać każdy z małżonków, zaś w świetle projektu unieważnienia związku partnerskiego - jak już wyżej wskazano - mógłby żądać każdy z partnerów. Jedyną różnicą między projektowanymi rozwiązaniami dotyczącymi związków partnerskich a obowiązującymi regulacjami odnoszącymi się do małżeństw jest to, iż brak jest odpowiednika $15 \$ 3$ k.r.o., który stanowi, że nie można unieważnić małżeństwa $\mathrm{z}$ powodu stosunku przysposobienia między małżonkami, jeżeli stosunek ten ustał. Należy z tego wnosić, iż projekt o z.p. zakłada nieco mniej rygorystyczne warunki unieważnienia związku partnerskiego z powodu istnienia stosunku przysposobienia między partnerami niż te, które ustanawia Kodeks rodzinny i opiekuńczy dla małżeństw.

BigAmia Jak wskazano wcześniej, w świetle projektu o z.p. unieważnić związek partnerski można, jeśli przynajmniej jeden z partnerów pozostaje w poprzednio zawartym małżeństwie albo związku partnerskim, a żądać jego unieważnienia z tej

$8 \quad$ Por. art. $10 \$ 4$ k.r.o., który stanowi: Jeżeli kobieta zaszła $w$ ciążę, jej mąż nie może żądać unieważnienia matżeństwa z powodu braku przepisanego wieku. 
przyczyny może każdy kto, ma w tym interes prawny. W tym miejscu należy zauważyć, iż takie same rozwiązania zawiera art. $16 \$ 2$ k.r.o., który stanowi, że: [u] nieważnienia małżeństwa z powodu pozostawania przez jednego z małżonków w poprzednio zawartym związku mał̇̇eńskim może żądać każdy, kto ma w tym interes prawny. Jako różnicę między rozwiązaniami Kodeksu rodzinnego i opiekuńczego a przepisami projektu o z.p. można wskazać to, iż projekt zakłada mniej rygorystyczne warunki unieważnienia związku partnerskiego z tego powodu, że jeden z partnerów pozostaje w poprzednio zawartym małżeństwie albo związku partnerskim niż te, które ustanawia Kodeks rodzinny i opiekuńczy dla małżeństw w przypadku bigamii. A mianowicie, brak jest przepisu analogicznego do art. $13 \$ 3$ k.r.o., który przewidywałby, że nie można unieważnić związku partnerskiego z powodu pozostawania przez jednego z partnerów w poprzednio zawartym związku małżeńskim lub partnerskim, jeżeli poprzedni związek ustał lub został unieważniony.

Pokrewieństwo I POWinowactwo Przeszkody pokrewieństwa oraz powinowactwa zostały uregulowane w projekcie o z.p. analogicznie jak w Kodeksie rodzinnym i opiekuńczym. Zarówno art. 5 ust. 1 zdanie pierwsze projektu, jak i art. $14 \$ 1$ zdanie pierwsze k.r.o. zakazują zawierania odpowiednio związków partnerskich oraz małżeństw pomiędzy krewnymi w linii prostej, rodzeństwem oraz powinowatymi w linii prostej. Ponadto art. 5 ust. 1 zdanie drugie identycznie tak jak art. $14 \$ 1$ zdanie drugie k.r.o. wskazuje, iż związek może zostać zawarty pomiędzy powinowatymi za zezwoleniem sądu, jeśli przemawiają za tym ważne powody. Niemniej zgodnie z art. 13 ust. 4 projektu o z.p. unieważnienia związku partnerskiego z powodu pokrewieństwa lub powinowactwa pomiędzy partnerami może żądać każdy, kto ma w tym interes prawny, natomiast w świetle art. $14 \$ 2-3$ k.r.o. unieważnienia małżeństwa $z$ powodu powinowactwa może żądać każdy z małżonków, a z powodu pokrewieństwa - każdy, kto ma w tym interes prawny.

WADY ośWiadczeń WOLI Projektowany art. 13 ust. 2 pkt 6 przyjmuje dla związków partnerskich rozwiązania zawarte w art. $15^{1} \$ 1$ pkt 2 i 3 k.r.o., który przewiduje, iż małżeństwo może być unieważnione, jeżeli oświadczenie o wstąpieniu w związek małżeński zostało złożone pod wpływem błędu co do tożsamości drugiej strony lub pod wpływem bezprawnej groźby drugiej strony lub osoby trzeciej, jeżeli z okoliczności wynika, że składający oświadczenie mógł się obawiać, iż jemu samemu lub innej osobie grozi poważne niebezpieczeństwo osobiste. Również art. 13 ust. 5 zdanie pierwsze projektu o z.p., przyznający legitymację do wytoczenia powództwa partnerowi, który złożył oświadczenie pod wpływem błędu lub bezprawnej groźby, powiela postanowienia art. $15 \$ 2$ k.r.o. Ponadto zdanie drugie art. 13 ust. 5 projektu o z.p., mówiące, że: [n]ie można żadać unieważnienia związk partnerskiego po upływie sześciu miesięcy od wykrycia błędu lub ustania obawy wywołanej groźba - a w każdym wypadku po upływie lat trzech od zawarcia partnerskiego, jest odpowiednikiem unormowań zawartych $\mathrm{w}$ art. $15^{1} \S 3$ k.r.o. 
Prima facie różnicą między przepisami Kodeksu rodzinnego i opiekuńczego a postanowieniami projektu jest to, że brak jest w nim odpowiednika art. $15^{1} \$ 1$ pkt 1 k.r.o., który przewidywałby możliwości unieważnienia związku partnerskiego, jeżeli oświadczenie o wstąpieniu w związek partnerski zostało złożone przez osobę, która z jakichkolwiek powodów znajdowała się w stanie wyłączającym świadome wyrażenie woli9. Jest to jednak tylko odmienność pozorna, bowiem w istocie podobne rozwiązanie zawiera art. 13 ust. 2 pkt 2 projektu o z.p., który stanowi: Związek partnerski może zostać unieważniony, jeśli decyzja o zawarciu związku nie została podjęta w sposób świadomy i swobodny.

CHOROBA PSYCHICZNA I NIEDOROZWój UMYsŁOWY W projekcie o z.p. brak jest przepisu, który wprost zakazywałby zawarcia związku partnerskiego osobie dotkniętej chorobą psychiczną albo niedorozwojem umysłowym, tak jak czyni to w stosunku do małżeństw art. $12 \$ 1$ k.r.o. Pomimo tego wydaje się jednak, że również przytoczony wyżej art. 13 ust. 2 pkt 2 projektu mógłby stanowić w większości przypadków podstawę unieważnienia związku partnerskiego, jeśli zostałby on zawarty przez osobę cierpiącą na chorobę psychiczną lub dotkniętą niedorozwojem umysłowym.

UbezwŁasnowolnienie Chociaż projekt o z.p. - inaczej niż Kodeks rodzinny i opiekuńczy - pomija przeszkodę ubezwłasnowolnienia całkowitego, to jednak biorąc pod uwagę art. $13 \$ 1$ k.c., który przewiduje, że: [o]soba, która ukończyła lat trzynaście, może być ubezwłasnowolniona całkowicie, jeżeli wskutek choroby psychicznej, niedorozwoju umysłowego albo innego rodzaju zaburzeń psychicznych, w szczególności pijaństwa lub narkomanii, nie jest w stanie kierować swym postępowaniem, należy przyjąć, że w istotnym zakresie ten brak mógłby eliminować art. 13 ust. 2 pkt 2 projektu.

ZaKaZ unieWAŻNienia zWIĄZKu po Jego ustaniu Kolejne łatwo dostrzegalne podobieństwa zawiera art. 13 ust. 6 projektu o z.p. oraz art. 18 k.r.o. Ten pierwszy wskazuje, że: nie można unieważnić związku partnerskiego po jego ustaniu. Nie dotyczy to jednak unieważnienia z powodu pokrewieństwa między partnerami oraz z powodu pozostawania przez jednego z partnerów $w$ chwili zawarcia małżństwa $w$ zawartym poprzednio związku partnerskim. Z kolei art. 18 k.r.o. stanowi: Nie można unieważnić matżeństwa po jego ustaniu. Nie dotyczy to jednak unieważnienia $z$ powodu pokrewieństwa między małżonkami oraz z powodu pozostawania przez jednego $z$ małżonków $w$ chwili zawarcia małżeństwa $w$ zawartym poprzednio związku małżeńskim.

Reasumując tę część analizy, należy stwierdzić, że regulacje dotyczące przesłanek unieważnienia małżeństwa oraz związku partnerskiego są analogiczne, różnią się tylko w szczegółach, jednak ich istota pozostaje taka sama.

9 Por. art. $15^{1} \$ 1$ pkt 1 k.r.o., który stanowi: Małżeństwo może być unieważnione, jeżeli oświadczenie o wstąpieniu $w$ związek małżeński lub oświadczenie przewidziane $w$ art. $1 \$ 2$ zostało złożone przez osobę, która z jakichkolwiek powodów znajdowała się $w$ stanie wyłączającym świadome wyrażenie woli. 


\section{- Nazwiska małżonków i partnerów}

Artykuł 7 ust. 9 projektu o z.p. przewiduje, że wraz z oświadczeniami o wstąpieniu w związek partnerski każdy z partnerów może złożyć oświadczenie o nazwisku, które będzie nosił po zawarciu związku. Zgodnie z tym przepisem wspólne nazwisko, jakie będą nosić partnerzy, może być dotychczasowym nazwiskiem jednego z nich lub połączeniem dotychczasowych nazwisk partnerów, z tym że nazwisko utworzone w wyniku połączenia nie może składać się z więcej niż dwóch członów. Z kolei art. $25 \$ 1$ k.r.o. stanowi, że: [o] nazwisku, które każdy $z$ małżonków będzie nosił po zawarciu małżeństwa, decyduje jego oświadczenie złożone przed kierownikiem urzędu stanu cywilnego. Oświadczenie może być złożone bezpośrednio po zawarciu małżeństwa albo przed sporządzeniem przez kierownika urzędu stanu cywilnego zaświadczenia stwierdzającego brak okoliczności wyłaczajacych zawarcie małżeństwa. W art. $25 \$ 2$ k.r.o. precyzuje się i stwierdza: Małżonkowie moga nosić wspólne nazwisko będace dotychczasowym nazwiskiem jednego $z$ nich. Każdy z małżonków może również zachować swoje dotychczasowe nazwisko albo połaczyć z nim dotychczasowe nazwisko drugiego małżonka. Nazwisko utworzone w wyniku połaczenia nie może składać się $z$ więcej niż dwóch członów.

Różnica pomiędzy przepisami Kodeksu rodzinnego i opiekuńczego a projektowanymi rozwiązaniami dla związków partnerskich jest nieznaczna. A mianowicie, $\mathrm{z}$ art. 7 ust. 9 projektu o z.p. wynika, że partner może złożyć oświadczenie o tym, iż: 1) będzie nosił swoje dotychczasowe nazwisko; 2) będzie nosił wspólne nazwisko będące dotychczasowym nazwiskiem jednego $\mathrm{z}$ nich lub połączeniem dotychczasowych nazwisk partnerów. Jako że przepis mówi o „wspólnym nazwisku, jakie będą nosić partnerzy”, należy przyjąć, iż w przypadku, o którym mowa w pkt 2, tym samym nazwiskiem dwuczłonowym musieliby posługiwać się obaj partnerzy. A zatem w świetle art. 7 ust. 9 - inaczej niż na gruncie Kodeksu rodzinnego i opiekuńczego - nie jest dopuszczalne, aby tylko jeden z partnerów nosił nazwisko dwuczłonowe składające się z jego dotychczasowego nazwiska i nazwiska drugiego partnera.

Mając na uwadze przepisy Kodeksu rodzinnego i opiekuńczego oraz projektowane rozwiązania, trzeba więc stwierdzić, że w analizowanym zakresie są one nie tylko podobne, ale niemalże identyczne.

\section{- Stosunki majątkowe}

Artykuł 14 ust. 1 projektu o z.p. przewiduje, że: [p]artnerzy moga ustanowić wspólność majątkowa poprzez zawarcie umowy w formie aktu notarialnego. Z kolei ust. 2 tego artykułu nakazuje do stosunków majątkowych między partnerami stosować odpowiednio przepisy tytułu I działu III rozdziału II Kodeksu rodzinnego i opiekuńczego dotyczące małżeńskich umownych ustrojów majątkowych. Wskazane przepisy projektu mogą budzić jednak wątpliwości interpretacyjne, dlatego na wstępie należy je wyjaśnić. 
Warto zauważyć, że art. 14 ust. 1, mówiąc o możliwości ustanowienia wspólności majątkowej poprzez zawarcie umowy w formie aktu notarialnego, sugeruje, iż chodzi o umowną wspólność majątkową. Jednak wydaje się, że projektodawcy chodziło o to, aby partnerzy mogli poprzez zawarcie umowy w formie aktu notarialnego uregulować między sobą stosunki majątkowe tak samo jak stosunki majątkowe małżonków regulują przepisy Kodeksu rodzinnego i opiekuńczego dotyczące ustawowej wspólności majątkowej. Stąd też dopiero w ust. 2 art. 14 nakazuje się do związków partnerskich odpowiednio stosować przepisy dotyczące małżeńskich umownych ustrojów majątkowych.

Mając powyższe na uwadze, należy uznać, że przyjęte w projekcie rozwiązania dopuszczają, aby stosunki majątkowe między partnerami były unormowane w ten sam sposób, jak między małżonkami, z tą różnicą, że ustrój będący odpowiednikiem małżeńskiej ustawowej wspólności majątkowej nie powstawałby między partnerami z mocy ustawy, lecz na podstawie umowy. Przy czym warto zauważyć, że brak regulacji kreujących wspólność majątkową między partnerami oznacza, iż w razie niezawarcia żadnej umowy ich stosunki majątkowe kształtowałyby się prawie tak samo jak w przypadku małżeńskiego ustroju rozdzielności majątkowej ${ }^{10}$. A więc, w istocie ustrój majątkowy, który - w razie niezawarcia umowy - dla małżonków jest obligatoryjny, dla partnerów byłby fakultatywny, zaś ten, który dla małżeństw jest fakultatywnym rozwiązaniem, w przypadku związków partnerskich byłby - w razie braku umowy majątkowej - rozwiązaniem obligatoryjnym.

Trzeba również dodać, że brak ustawowego ustroju wspólności majątkowej nie jest rozwiązaniem, które dostatecznie różnicuje związek partnerski od małżeństwa. Warto bowiem zauważyć, że np. w Portugalii wówczas, gdy małżeństwo jest zawierane przez osobę, która ukończyła 60 lat, z mocy ustawy powstaje ustrój rozdzielności majątkowej ${ }^{11}$, co nie oznacza przecież, iż związek ten różni się od małżeństwa zawieranego przez osoby młodsze na tyle, że należałoby go nazywać związkiem partnerskim.

\section{- Rozwiązanie małżeństwa i związku partnerskiego}

Zgodnie z art. $56 \$ 1$ k.r.o. pozytywną przesłanką rozwodu jest zupełny i trwały rozkład pożycia między małżonkami. W tym wypadku każdy z małżonków

10 Prawie tak samo, ponieważ projektodawcy nie zmieniają na art. $680^{1} \S 1$ k.c., który stanowi: Małżonkowie sq najemcami lokalu bez względu na istniejące między nimi stosunki majątkowe, jeżeli nawiązanie stosunku najmu lokalu mającego służyć zaspokojeniu potrzeb mieszkaniowych założonej przez nich rodziny nastąiło w czasie trwania małżeństwa. Jeżeli między małżonkami istnieje rozdzielność majątkowa albo rozdzielność majątkowa $z$ wyrównaniem dorobków do wspólności najmu stosuje się odpowiednio przepisy o wspólności ustawowej.

11 Art. 1720 ust. 1 lit. b portugalskiego kodeksu cywilnego (Código Civil) z 25 listopada 1966 r., http://www.pgdlisboa.pt/leis/lei_mostra_articulado.php?ficha=1\&artigo_id= \&nid=775\&pagina $=1 \&$ tabela $=$ leis\&nversao $=\&$ so_miolo $=$ [dostęp 20 czerwca 2018 r.] 
może żądać, aby sąd rozwiązał małżeństwo przez rozwód. Negatywne przesłanki rozwodu formułuje art. $56 \$ 2$ i 3 k.r.o. W świetle pierwszego z tych przepisów pomimo zupełnego i trwałego rozkładu pożycia rozwód nie jest dopuszczalny, jeżeli wskutek niego miałoby ucierpieć dobro wspólnych małoletnich dzieci małżonków albo jeżeli z innych względów orzeczenie rozwodu byłoby sprzeczne z zasadami współżycia społecznego. Z kolei art. $56 \$ 3$ k.r.o. przewiduje, że rozwód nie jest też dopuszczalny, jeżeli żąda go małżonek wyłącznie winny rozkładu pożycia, chyba że drugi małżonek wyrazi zgodę na rozwód albo że odmowa jego zgody na rozwód jest w danych okolicznościach sprzeczna z zasadami współżycia społecznego.

Natomiast w świetle projektowanych rozwiązań związek partnerski zostaje rozwiązany na skutek złożenia przed kierownikiem urzędu stanu cywilnego zgodnych oświadczeń woli o rozwiązaniu związku (art. 10 pkt 1 oraz art. 11 ust. 1 projektu o z.p.). Fakultatywnie oświadczenia te mogą być złożone przed konsulem (art. 11 ust. 3 projektu o z.p.). Jeżeli zaś jeden z partnerów nie wyraża zgody na zakończenie związku, drugi może żądać jego rozwiązania na drodze sądowej (art. 11 ust. 4 projektu o z.p.). Mając na uwadze art. 4 pkt 4 projektu przep.wprow.u.z.p., który zakłada dodanie do Kodeksu rodzinnego i opiekuńczego art. 61a nakazującego stosować przepisy działu IV Kodeksu rodzinnego i opiekuńczego odpowiednio do ustania związku partnerskiego, należy przyjąć, iż w razie braku porozumienia partner mógłby domagać się rozwiązania związku na podstawie art. 56 k.r.o., który określa przesłanki rozwodu.

Ponadto, jak przewiduje art. 12 ust. 1 projektu o z.p., jeżeli w trakcie trwania związku jeden z partnerów przysposobił dziecko drugiego partnera, ustanie związku partnerskiego może nastąpić przez jednoczesne złożenie zgodnych oświadczeń przez partnerów wyłącznie wtedy, gdy partnerzy zawrą pisemne porozumienie o sposobie wykonywania władzy rodzicielskiej i utrzymywaniu kontaktów z dzieckiem po rozwiązaniu związku partnerskiego, a sąd je zaakceptuje. Natomiast - jak dodaje ten przepis - w przypadku braku możliwości zawarcia porozumienia, by rozwiązać związek partnerski, każdy z partnerów ma prawo żądać, aby związek został rozwiązany przez sąd ${ }^{12}$.

Przedstawione porównanie pokazuje, że proponowane przesłanki rozwiązania związku partnerskiego są mniej rygorystyczne niż występujące w Kodeksie rodzinnym i opiekuńczym przesłanki rozwodu małżonków. Niemniej nie oznacza to, że możliwość rozwiązania związku na podstawie zgodnych oświadczeń woli sprawia, iż związek ten nie może być już uważany za związek małżeński. Rozwód na podstawie porozumienia małżonków występuje np. w Estonii ${ }^{13}$, Por-

12 Zob. niżej również uwagi szczegółowe na temat art. 12 projektu o z.p.

13 Zob. $\$ 64$ oraz $\$ 64^{1}$ estońskiego kodeksu prawa rodzinnego z 18 listopada 2009 r. Aktualna wersja kodeksu w języku estońskim wraz z tłumaczeniem na język angielski dostępne są na stronie internetowej oficjalnego publikatora aktów praw- 
tugalii ${ }^{14}$ oraz Rumunii ${ }^{15}$. Ponadto zgodna wola rozwiązania małżeństwa, pod warunkiem że małżonkowie nie utrzymują pożycia przez okres prawem oznaczony, może uzasadniać rozwód np. w Niemczech ${ }^{16}$ oraz Chile ${ }^{17}$.

\section{- Adopcja dzieci przez osoby będące w związku partnerskim}

Artykuł 17 ust. 1 projektu o z.w. stanowi, że: [p] artner może przysposobić zstępnego drugiego partnera, w pierwszym stopniu pokrewieństwa, na zasadach określonych w Tytule II Dziale II ustawy z dnia 25 litego 1964 - Kodeks rodzinny i opiekuńczy. Ponadto art. 17 ust. 2 przewiduje, że w razie: wyrażenia zgody przez partnera, którego zstępnego przysposobienia dotyczy oraz drugiego rodzica osoby przysposabianej posiadajacego pełnię władzy rodzicielskiej, przy braku sprzeciwu ze strony przysposabianego, sąd może odmówić przysposobienia jedynie $z$ ważnych przyczyn dotyczacych dobra przysposabianego. Jak dodaje ust. 3 tego artykułu, płeć partnera przysposabiającego nie może stanowić podstawy odmowy przysposobienia.

Może wydawać się, że projekty przewidują tylko możliwość przysposobienia zstępnego partnera, w pierwszym stopniu pokrewieństwa. Jednak uważna lektura art. 4 pkt 16 projektu przep.wprow.u.z.p. prowadzi do innych wniosków. Przepis ten zakłada dodanie do Kodeksu rodzinnego i opiekuńczego art. $127^{1}$ w następującym brzmieniu: Przepisy niniejszego Działu stosuje się odpowiednio do przysposobienia dziecka przez partnerów lub partnera $w$ ramach związku partnerskiego, w rozumieniu przepisów ustawy o związku $z$ partnerskim, $z$ zastrzeżeniem przepisów art. 14 ustawy o związku partnerskim. W zakresie, w jakim przepisy niniejszego Działu przewiduja prawa lub obowiązki wobec małżonków, stosuje się je odpowiednio do partnerów związku partnerskiego [wyróżnienie - R.D.] ${ }^{18}$.

Po pierwsze, należy wyjaśnić, że dział, do którego odsyła projektowany art. $127^{1}$ k.r.o., to dział regulujący kwestie związane $\mathrm{z}$ adopcją dziecka. Po drugie,

nych Riigi Teataja: https://www.riigiteataja.ee/en/eli/ee/503042014005/consolide/ current\#659e8667-21b4-4357-940f-c379e23ff67d [dostęp 20 czerwca 2018 r.].

14 Zob. art. 1773 ust. 1-2 portugalskiego kodeksu cywilnego z 25 listopada 1966 r., http://www.pgdlisboa.pt/leis/lei_mostra_articulado.php?ficha=1\&artigo_id=\&nid=7 75\&pagina $=1 \&$ tabela $=$ leis\&nversao=\&so_miolo $=$ [dostęp 20 czerwca 2018 r.].

15 Zob. art. 373 ust. 1 rumuńskiego kodeksu cywilnego z 17 lipca 2009 r. Kodeks w języku rumuńskim dostępny na stronie portalu legislacyjnego Legislativ: http://legislatie. just.ro/Public/DetaliiDocument/109884\#id_crtA139_ttl [dostęp 20 czerwca 2018 r.].

16 Zob. $\$ 1566$ ust. 1 niemieckiego kodeksu cywilnego z 1896 r., http://www.gesetze-im-internet.de/bgb/index.html [dostęp 20 czerwca 2018 r.].

17 Zob. art. 55 ustawy nr 19947 o małżeństwie cywilnym (Ley núm. 19.947, Nueva Ley de matrimonio civil), https://www.leychile.cl/Navegar?idNorma=225128 [dostęp 20.06.2018 r.]; M. Tapia Rodríguez, El divorcio en el derecho chileno [w:] El divorcio en el derecho iberoamericano, red. Á. Acedo Penco, L.B. Pérez Gallardo, Bogota, Meksyk, Madryd, Buenos Aires 2009, s. 149-151.

18 Zob. niżej uwagi szczegółowe do art. 4 pkt 16 projektu przep.wprow.u.z.p. 
trzeba zauważyć, że art. $127^{1}$ nie tylko wskazuje, iż przepisy tego działu stosuje się odpowiednio do przysposobienia dziecka przez partnera, ale także przewiduje ich odpowiednie stosowanie w przypadku adopcji dziecka przez obu partnerów. Ponieważ projektowany art. $127^{1}$ posługuje się liczbą mnogą "partnerzy”, należy przyjąć, że nie odnosi się on tylko do dopuszczonej przez art. 17 projektu o z.w. możliwości przysposobienia dziecka jednego z partnerów przez drugiego partnera, lecz dopuszcza także, by adoptowali oni wspólnie dzieci, które nie są zstępnymi jednego $z$ nich.

W związku z powyższym w konkluzji trzeba stwierdzić, że projektowane regulacje $\mathrm{w}$ zakresie dotyczącym przysposobienia zrównują prawa i obowiązki partnerów oraz małżonków. Ponadto - mając na uwadze, że w świetle art. 2 projektu o z.w. związek partnerski mógłby być zawarty przez pary jednopłciowe - należy dodać, że wskazane jest, by projektowane regulacje dotyczące adopcji dzieci zostały zaopiniowane przez ekspertów z innych nauk społecznych, zwłaszcza przez specjalistów z dziedziny psychologii. W szczególności należałoby wyjaśnić, w jaki sposób wychowanie przez pary homoseksualne wpływa na rozwój dziecka. Odpowiedź udzielona przez osoby specjalizujące się w innych, nieprawniczych dziedzinach wiedzy nie może pozostać bez znaczenia dla oceny prawnej dopuszczalności wprowadzenia proponowanych regulacji. Ochrona dobra dziecka jest bowiem zasadą konstytucyjną ${ }^{19}$, która jest realizowana przez liczne postanowienia Kodeksu rodzinnego i opiekuńczego, a w szczególności przez te dotyczące przysposobienia ${ }^{20}$.

\section{Konkluzja}

Przedstawiona wyżej analiza porównawcza prowadzi do wniosku, że projektowane rozwiązania dotyczące związków partnerskich są analogiczne, w wysokim stopniu zbliżone do tych zawartych w obowiązujących przepisach odnoszących się do małżeństw. Co więcej, w wielu miejscach są one takie same albo prawie identyczne. Należy również dodać, iż projekt przep.wprow.u.z.p. modyfikuje obowiązujące przepisy w ten sposób, aby regulacje dotyczące małżonków miały zastosowanie także do partnerów tworzących związek partnerski. Prawie wszystkie zaproponowane tam zmiany polegają na dodaniu zwrotu „związek partnerski w rozumieniu ustawy o związku partnerskim", w formie adekwatnej do treści obowiązującego przepisu oraz wprowadzeniu regulacji, które nakazują odpowiednie stosowanie do związków partnerskich przepisów dotyczących małżeństwa. Ten obszerny projekt mógłby niemalże w całości zostać zastąpiony przez dodanie do projektu o z.p. takich rozwiązań, które przewidywałyby, że ilekroć w odrębnej ustawie jest mowa o małżeństwie lub małżonku należy przez to także

19 Zob. w szczególności art. 72 Konstytucji.

20 Zob. zwłaszcza art. 114 k.r.o., który przewiduje, że przysposobić można małoletniego tylko dla jego dobra. 
rozumieć odpowiednio związek partnerski lub partnera w rozumieniu ustawy o związku partnerskim.

Mając powyższe na uwadze, należy stwierdzić, że opiniowane projekty ustaw wbrew stosowanemu w nich nazewnictwu - nie wprowadzają instytucji związku partnerskiego, lecz ustanawiają instytucję małżeństwa jednopłciowego, a przez to mogą być uznane za niezgodne $\mathrm{z}$ art. 18 Konstytucji.

Bynajmniej konkluzji tej nie przeczą drobne różnice występujące między obowiązującymi przepisami prawa małżeńskiego a regulacją przeznaczoną dla związków partnerskich. Należy bowiem zauważyć, że jeśli nie we wszystkich, to przynajmniej w większości państw na świecie obowiązują inne niż w Polsce unormowania dotyczące małżeństwa, nie oznacza to jednak, iż związki zawarte według obcego prawa nie mogą być uznawane za małżeństwa. Dobitnie świadczą o tym regulacje ustawy z 4 lutego 2011 r. - Prawo prywatne międzynarodowe, które pozwalają stosować $\mathrm{w}$ sprawach małżeńskich powiązanych $\mathrm{z}$ systemami prawnymi innych państw - prawo obce ${ }^{21}$.

Jednocześnie należy wskazać, że nawet gdyby projektodawca zdecydował się wyeliminować z projektów przepisy pozwalające na zawieranie związków partnerskich przez osoby tej samej płci, to i tak ocena dotycząca (nie)konstytucyjności proponowanych regulacji pozostałaby taka sama, ponieważ związek mężczyzny i kobiety niebędący małżeństwem nie może pozostawać pod opieką i ochroną, która jest przewidziana dla małżeństw ${ }^{22}$.

\section{Uwagi szczegółowe}

SKUTKi UNIEWAŻNiENIA ZWIĄZKU PARTNERSKIEGo Mimo że projekt o z.p. określa przesłanki unieważnienia związku partnerskiego, to w żadnym z opiniowanych projektów nie ma rozwiązań, które pozwalałyby ustalić, jakie skutki powoduje unieważnienie w zakresie stosunku partnerów do wspólnych dzieci oraz w zakresie stosunków majątkowych między partnerami. Ponadto projekty nie rozstrzygają o tym, czy w przypadku unieważnienia związku partnerskiego sąd orzeka także, czy i który z partnerów zawarł związek w złej wierze (por. art. 20 k.r.o.).

Art. 1 Projektu o z.w. Przepis ten stanowi, że: [u] stawa określa zasady zawierania i ustania związk partnerskiego, wzajemne prawa i obowiązki partnerów oraz stosunki majątkowe pomiędzy partnerami. Należy jednak zauważyć, iż art. 17 tegoż projektu reguluje kwestie związane z przysposobieniem przez partnera zstępnych drugiego partnera. W związku z tym, że przysposobienie wywołuje

${ }^{21}$ Zob. w szczególności art. 48-54 tej ustawy. Wyjątek od stosowania prawa obcego wprowadza art. 7 ustawy - Prawo prywatne międzynarodowe, który stanowi, że: [p] rawa obcego nie stosuje sie, jeżeli jego stosowanie miałoby skutki sprzeczne z podstawowymi zasadami porzadku prawnego Rzeczypospolitej Polskiej.

22 Por. W. Borysiak, Komentarz do art. 18, op. cit., nb 129. 
przede wszystkim skutki prawne między przysposabiającym i przysposobionym, a nie między partnerami, należy stwierdzić, iż przedmiot ustawy został $\mathrm{w}$ art. 1 projektu błędnie określony.

ART. 3 UST. 1 PROJEKTU O z.w. Stanowi on, że: [p] rzez zawarcie zwiazku partnerskiego partnerzy zobowiązuja się do pozostawania we wspólnym pożyciu, obejmującym wzajemny szacunek $i$ wspieranie. Trzeba w tym miejscu zauważyć, że proponowane rozwiązanie sprowadza wspólne pożycie do wzajemnego szacunku i wspierania się. W świetle treści przepisu bynajmniej nie można uznać, że wzajemny szacunek i wspieranie się są tylko przykładami elementów konstytuujących wspólne pożycie, bowiem gdyby tak było, to art. 3 ust. 1 posługiwałby się zwrotem „w szczególności”.

Natomiast - jak wskazuje się w piśmiennictwie prawniczym oraz orzecznictwie - wspólne pożycie polega na duchowej, fizycznej i gospodarczej więzi i powinno ono bazować na uczuciu miłości, lojalności i szczerości, wzajemnych stosunkach intymnych i prowadzeniu wspólnego gospodarstwa domowego ${ }^{23} . \mathrm{Na}$ tle powyższego stanowiska trzeba stwierdzić, że art. 3 ust. $1 \mathrm{w}$ istotny sposób redukuje pojęcie „wspólnego pożycia” i dlatego należałoby go zmodyfikować.

Ponadto, mając na uwadze treść oświadczenia o wstąpieniu w związek partnerski, w którym partner przyrzeka, że uczyni wszystko, aby związek był zgodny, szczęśliwy i trwały (zob. art. 7 ust. 5 projektu o z.w.), wątpliwości budzi brak przepisu, który formułowałby prawny obowiązek wierności oraz współdziałania dla dobra zawartego związku. Chociaż naruszenie tych obowiązków nie wiązałoby się z żadną bezpośrednią sankcją, to jednak stanowiłoby wyznacznik pozwalający orzekać o winie rozkładu pożycia w przypadku rozwiązania związku partnerskiego na drodze sądowej (zob. art. 11 ust. 4 projektu o z.p. oraz art. 56 k.r.o. w związku z art. 4 pkt 4 projektu przep.wprow.u.z.p.).

ART. 9 UST. 2 PROJeKTU o z.P. Należy przypuszczać, że w przepisie tym błędnie odwołano się do art. 6 ust. 4 i 8 projektu o z.p., bowiem art. 6 nie jest podzielony na ustępy. Uwzględniając sens regulacji, można wnosić, że projektodawcy chodziło o art. 7 ust. 4 i 8 projektu o z.p.

ART. 12 PROjeKtu o Z.W. [Nierówne traktowanie WSPÓLNYCH DZieci PARTNERÓW I DZIECI PRZYSPOSOBIONYCH] W świetle art. 12 ust. 1, w przypadku

23 Zob. np. K. Gromek, Kodeks rodzinny i opiekuńczy. Komentarz, Warszawa 2018, komentarz do art. 23, nb 2; J. Gajda, Komentarz do art. 23 [w:] Kodeks rodzinny i opiekuńczy. Komentarz, red. K. Pietrzykowski, Warszawa 2018, nb 12; uchwała SN z 28 maja 1955 r., sygn. akt I CO 5/55, OSNCK 1955, nr 3, poz. 46, w której stwierdza się, że: pożycie małżeńskie wyraża się w szczególnego rodzaju wspólnocie duchowej, fizycznej i gospodarczej; wyrok SN z 22 października 1999 r., sygn. akt III CKN 386/98, Legalis $\mathrm{nr}$ 342590, gdzie stwierdza się: zgodnie $z$ utrwalonym $w$ orzecznictwie pogladem, nie kwestionowanym $w$ doktrynie, wspólne pożycie $w$ rozumieniu art. 23 k.r.o. polega na duchowej, fizycznej oraz gospodarczej więzi matżonków, stanowiącej cel matżeństwa i umożliwiajaccej realizacje jego podstawowych zadań. 
gdy w trakcie trwania związku jeden z partnerów przysposobił dziecko drugiego partnera, ustanie związku partnerskiego może nastąpić przez jednoczesne złożenie zgodnych oświadczeń przez partnerów wyłącznie wtedy, gdy partnerzy zawrą pisemne porozumienie o sposobie wykonywania władzy rodzicielskiej i utrzymywaniu kontaktów z dzieckiem po rozwiązaniu związku partnerskiego, a sąd je zaakceptuje. Natomiast - jak dodaje ten przepis - w razie braku możliwości zawarcia porozumienia, by rozwiązać związek partnerski, każdy z partnerów ma prawo żądać, aby związek został rozwiązany przez sąd.

Przedstawione rozwiązanie budzi istotne zastrzeżenia i wskazuje na brak spójności aksjologicznej projektowanych regulacji, ponieważ ogranicza dopuszczalność rozwiązania związku przez złożenie zgodnych oświadczeń tylko do takich sytuacji, gdy między partnerami brak jest porozumienia o sposobie wykonywania władzy rodzicielskiej z dzieckiem przysposobionym. Należy jednak zwrócić uwagę, iż związki partnerskie - zgodnie z art. 2 projektu o z.w. mogłyby być zawierane przez osoby różnej płci, a ponadto art. 4 pkt 6 projektu przep. wprow.u.z.p. - zmieniając art. 62 k.r.o. - wprowadzałby domniemanie pochodzenia dziecka od partnera matki. Dlatego dopuszczalność rozwiązania związku partnerskiego na podstawie zgodnego oświadczenia w razie braku porozumienia o sposobie wykonywania władzy rodzicielskiej i utrzymywaniu kontaktów ze wspólnym dzieckiem partnerów jest niezrozumiałe.

Zresztą, co należy też podkreślić, nawet w sytuacji, gdy partnerzy „rozwodzący się" na podstawie zgodnych oświadczeń woli przygotowaliby pisemne porozumienie dotyczące wykonywania władzy rodzicielskiej i utrzymywania kontaktów z ich wspólnym dzieckiem, to w świetle projektowanych rozwiązań nie musiałoby ono zostać zatwierdzone przez sąd ani innych organ, bowiem art. 12 ust. 2, który mówi o warunkach uwzględnienia tego rodzaju porozumienia, odnosi się do sądowego trybu rozwiązania związku partnerskiego, o czym świadczy to, że rozpoczyna się on od słów: „W wyroku orzekającym rozwiązanie związku partnerskiego...”.

Mając powyższe na uwadze, należy dojść do wniosku, że projektowane rozwiązania zapewniają słabszą ochronę wspólnym dzieciom partnerów niż dzieciom jednego $\mathrm{z}$ nich przysposobionym przez drugiego, co jest niezgodne $\mathrm{z}$ konstytucyjną zasadą równości.

ART. 13 UST. 6 PROJEKTU O Z.W. I ART. 4 PKT 2 PROJEKTU PRZEP.WPROW.U.Z.P. Warto zauważyć, że art. 13 ust. 6 projektu o z.w. omyłkowo mówi, iż zakaz unieważnienia związku po jego ustaniu nie dotyczy unieważnienia: $z$ powodu pozostawania przez jednego $z$ partnerów $w$ chwili zawarcia małżeństwa $w$ zawartym poprzednio związu partnerskim, jak zaś można przypuszczać powinno być: w chwili zawarcia związku partnerskiego.

Poza tym, skoro przepis ten przewiduje, że ustanawiany w nim zakaz nie dotyczy unieważnienia $\mathrm{z}$ powodu pozostawania przez jednego z partnerów w poprzednio zawartym związku partnerskim, to tym bardziej powinien wyłączać 
stosowanie zakazu unieważnienia związku po jego ustaniu wówczas, gdy jeden $\mathrm{z}$ partnerów pozostawał w uprzednio zawartym małżeństwie.

Wobec tego, że art. 13 ust. 6 zdanie pierwsze projektu o z.p. przewiduje, że: [n] ie można unieważnić zwiąku partnerskiego po jego ustaniu, zbędne jest powielanie tego zapisu w art. 18 zdanie pierwsze k.r.o., który - zgodnie z art. 4 pkt 2 projektu przep.wprow.u.z. - po nowelizacji miałby stanowić: Nie można unieważnić małżeństwa lub zwiąku partnerskim w rozumieniu przepisów ustawy o zwiąku partnerskim, po ich ustaniu ${ }^{24}$.

Na marginesie warto dodać, że w projekcie art. 18 zdanie pierwsze k.r.o. występuje błąd. Zamiast „Związku partnerskim” winno być „Związku partnerskiego”. $\mathrm{Z}$ kolei w art. 13 ust. 6 brak jest kropki na końcu zdania.

ART. 4 PKT 5 PROJEKTU PRZEP.WPROW.U.Z.P. [DOMNIEMANIE POCHODZENIA DZIECKA] Artykuł 4 pkt 6 projektu przep.wprow.u.z.p. zakłada zmianę art. $62 \$ 1$ i 2 k.r.o. W świetle projektu art. $62 \$ 1$ uzyskałby następujące brzmienie: Jeżeli dziecko urodziło się $w$ czasie trwania małżeństwa albo związu partnerskiego, albo przed uplywem trzystu dni od ich ustania lub unieważnienia, domniemywa się, że pochodzi ono od męża albo partnera matki. Domniemania tego nie stosuje się, jeżeli dziecko urodziło się po uplywie trzystu dni od orzeczenia separacji. Z kolei art. $62 \$ 2$ proponuje się nadać następującą treść: Jeżeli dziecko urodzito się przed uplywem trzystu dni od ustania lub unieważnienie matżeństwa albo związku partnerskiego, lecz po zawarciu przez matkę drugiego małżeństwa albo zwiazku partnerskiego, domniemywa się, że pochodzi ono od drugiego męża albo partnera. Domniemanie to nie dotyczy przypadku, gdy dziecko urodziło się $w$ następstwie procedury medycznie wspomaganej prokreacji, na która wyrazit zgodę pierwszy mąż matki albo partner.

Na tle tych przepisów warto zwrócić uwagę, że art. 2 pkt 2 projektu o z.p. przewiduje, iż partnerem jest osoba fizyczna pozostająca w związku partnerskim, niezależnie od jej płci. W związku z tym użycie w art. $62 \$ 1$ i 2 k.r.o. rzeczownika rodzaju męskiego „partner” nie wyklucza stosowania zawartych tam domniemań ojcostwa w stosunku do kobiety będącej w związku partnerskim z matką dziecka. Innymi słowy, należy stwierdzić, że projektowane przepisy stwarzają możliwość zafałszowania rzeczywistości biologicznej i uznania kobiety za ojca dziecka.

ART. 4 PKT 16 PROJeKTU PRZEP.WPROW.U.z.P. Przepis ten zakłada dodanie do Kodeksu rodzinnego i opiekuńczego art. $127^{1} \mathrm{w}$ następującym brzmieniu: Przepisy niniejszego Działu stosuje się odpowiednio do przysposobienia dziecka przez partnerów lub partnera $w$ ramach związku partnerskiego, $w$ rozumieniu przepisów ustawy o związku z partnerskim, z zastrzeżeniem przepisów art. 14 ustawy o zwiazku partnerskim. W zakresie, w jakim przepisy niniejszego Działu przewiduja prawa lub obowiązki wobec małżonków, stosuje się je odpowiednio do partnerów związku partnerskiego. Biorąc pod uwagę, że w art. 14 projektu o z.p. jest

${ }^{24}$ Zob. art. 4 pkt 2 projektu przep.wprow.u.z.p. 
mowa o ustrojach majątkowych, należy przypuszczać, iż projektodawcy chodziło $\mathrm{o}$ art. 17 projektu o z.p., który reguluje kwestie związane z przysposobieniem.

ART. 5 PKT 2 PROJEKTU PRZEP.WPROW.U.Z.P. W przepisie tym proponuje się zmianę art. $43^{8} \$ 1$ k.c., który po nowelizacji miałby otrzymać następujące brzmienie: W przypadku utraty członkostwa przez wspólnika, którego nazwisko było umieszczone w firmie, spółka może zachować w swej firmie nazwisko byłego wspólnika tylko za wyrażona na piśmie jego zgoda, a w razie jego śmierci - za zgoda jego małżonka albo partnera $w$ rozumieniu przepisów ustawy o związku partnerskim, a także zgody jego dzieci. Wydaje się, iż powinno być: a także po uzyskaniu zgody jego dzieci albo a także za zgoda jego dzieci.

ArT. 5 PKT 11 PROJEKTU PRZEP.WPROW.U.Z.P. Przepis ten nie przewiduje żadnej zmiany, lecz powtarza treść obowiązującego art. 936 k.c.

ART. 5 PKT 12 PROJEKTU PRZEP.WPROW.U.Z.P. Przepis ten stanowi, że: art. 937 otrzymuje brzmienie: „Art. 939 (...)”. Oznaczenie art. 937 k.c. numerem 939 jest w sposób oczywisty niezgodne z zasadami techniki prawodawczej.

ART. 5 PKT 13 PROJEKTU PRZEP.WPROW.U.Z.P. W przepisie tym proponuje się nowelizację art. 940 k.c. Paragraf 2 tego artykułu miałby stanowić, że: [w]yłączenie małżonka od dziedziczenia następuje na mocy orzeczenia sąu. Wyłaczenia może żadać każdy z pozostałych spadkobierców ustawowych powołanych do dziedziczenia $w$ zbiegu z małżonkiem albo partnerem; termin do wytoczenia powództwa wynosi sześć miesięcy od dnia, w którym spadkobierca dowiedział się o otwarciu spadku, nie więcej jednak niż jeden rok od otwarcia spadku.

Biorąc pod uwagę, że art. 5 pkt 12 projektu przep.wprow.u.z.p. zmienia także $\$ 1$ art. 940 k.c. i przewiduje wyłączenie partnera od dziedziczenia, jeżeli spadkodawca wystąpił o rozwiązanie związku partnerskiego, w toku ewentualnych prac legislacyjnych należałoby wyjaśnić, dlaczego w zdaniu pierwszym proponowanego art. $940 \$ 1$ k.c. jest mowa tylko o wyłączeniu małżonka.

ART. 6 PKT 10 PROJEKTU PRZEP.WPROW.U.Z.P. Przepis ten przewiduje, że: $w$ Tytule VII, Dział I dodaje się Rozdział 4 brzmieniu: „Sprawy z zakresu związków partnerskich $w$ rozumieniu przepisów ustawy o związku partnerskim”. Oprócz tego, że brak jest litery „w” pomiędzy cyfrą „4” a wyrazem „brzmieniu”, należy przede wszystkim zauważyć, że przepis ten ani żaden inny nie określa, jaka miałaby być treść tego rozdziału.

ArT. 106 PROJEKTU PRZEP.WPROw.U.Z.P. Ponieważ projektowana regulacja zakłada nowelizację ustawy z 27 lipca 2005 r. - Prawo o szkolnictwie wyższym (t.j. Dz.U. 2017, poz. 2183, ze zm.), warto mieć na uwadze to, że w parlamencie toczą się prace nad reformą systemu szkolnictwa wyższego ${ }^{25}$. Zgodnie $\mathrm{z}$ art. 165 pkt 3 rządowego projektu ustawy - Przepisy wprowadzające ustawę - Prawo

25 Zob. rządowy projekt ustawy - Prawo o szkolnictwie wyższym i nauce (druk sejmowy nr 2446) oraz rządowy projekt ustawy - Przepisy wprowadzające ustawę - Prawo o szkolnictwie wyższym i nauce (druk sejmowy nr 2447). 
o szkolnictwie wyższym i nauce z dniem wejścia w życie tej ustawy obowiązujące Prawo o szkolnictwie wyższym utraci moc z wyjątkiem: a) art. 112a, który utraci moc z dniem 1 czerwca 2018 r., b) oraz art. 98, art. 100, art. 101, art. 102, art. 103, art. 103a, art. 104 i art. 106, które utracą moc z dniem 31 grudnia 2018 r. W związku z powyższym w toku ewentualnych prac nad opiniowanym projektem należałoby uwzględnić wyniki procesu legislacyjnego w zakresie dotyczącym szkolnictwa wyższego.

\section{Podsumowanie}

- Projektowane przepisy - wbrew stosowanemu w nich nazewnictwu - wprowadzają instytucję małżeństwa jednopłciowego i dlatego mogą zostać uznane za niezgodne $\mathrm{z}$ art. 18 Konstytucji.

- Ponieważ projekty dopuszczają adopcję dzieci przez pary homoseksualne, wskazane jest, by rozwiązanie to zostało zaopiniowane również przez ekspertów z innych nauk społecznych, zwłaszcza przez specjalistów z dziedziny psychologii. W szczególności powinni oni wszechstronnie ocenić, czy proponowane rozwiązania nie zagrażają prawidłowemu rozwojowi adoptowanego dziecka i nie sprzeciwiają się jego dobru.

- Artykuł 4 pkt 5 projektu ustawy - Przepisy wprowadzające ustawę o związku partnerskim w związku z art. 2 pkt 2 projektu ustawy o związku partnerskim stwarza możliwość zafałszowania rzeczywistości biologicznej i dopuszcza uznanie kobiety za ojca dziecka.

- Projektowane regulacje dotyczące rozwiązania związku partnerskiego zapewniają słabszą ochronę wspólnym dzieciom partnerów niż dzieciom jednego $\mathrm{z}$ nich przysposobionym przez drugiego, co jest niezgodne $\mathrm{z}$ konstytucyjną zasadą równości.

- Projekty zawierają inne istotne - choć nie tak doniosłe jak te wskazane wyżej mankamenty. W szczególności zaś w projekcie ustawy o związku partnerskim błędnie określono jej przedmiot, istotnie zredukowano pojęcie wspólnego pożycia oraz nie uregulowano skutków unieważnienia związku partnerskiego. Z kolei w drugim z opiniowanych projektów występują błędy redakcyjne, które w razie jego uchwalenia w tej formie miałyby daleko idące negatywne skutki.

\section{Bibliografia}

Borysiak W., Komentarz do art. 18 [w:] Konstytucja RP, t. I, Komentarz. Art. 1-86, red. M. Safjan, L. Bosek, Warszawa 2016.

Gajda J., Komentarz do art. 23 [w:] Kodeks rodzinny i opiekuńczy. Komentarz, red. K. Pietrzykowski, Warszawa 2018. 
Garlicki L., Komentarz do art. 18 [w:] Konstytucja Rzeczypospolitej Polskiej. Komentarz, t. I, red. L. Garlicki, M. Zubik, Warszawa 2016.

K. Gromek, Kodeks rodzinny i opiekuńczy. Komentarz, Warszawa 2018.

Tapia Rodríguez M., El divorcio en el derecho chileno [w:] El divorcio en el derecho iberoamericano, red. Á. Acedo Penco, L.B. Pérez Gallardo, Bogota-Meksyk-MadrydBuenos Aires 2009. 